\title{
The Approaches to Philological Competence as an Integral Part of Professional Competence of a Foreign Language Teacher
}

\author{
Irina M. Komiakova* \\ State University of Humanities and Social Studies \\ 30 Zelenaia Str., Kolomna, Moscow region, 140410, Russia
}

Received 22.10.2015, received in revised form 04.11.2015, accepted 10.12.2015

The article is devoted to the issues of the philological competence and the importance of developing it in the process of training Bachelors of Education (Major in Foreign Languages) at high school. First of all, it studies various points of view on the terms "philology" and "philological competence". In addition, it presents the approaches to the main characteristics of the philological competence and singles out the required skills and abilities of future foreign language teachers. As a result, it suggests the way to develop the philological competence using the interdisciplinary approach.

Keywords: philological competence, Bachelor of Education (Major in Foreign Languages), professional competence of a foreign language teacher, interdisciplinary approach.

DOI: 10.17516/1997-1370-2016-9-1-229-233.

Research area: pedagogics, methodology.

\section{Introduction}

The problem of development of different competences in the structure of professional competence of Bachelors of Education (Major in Foreign Languages) has been investigated in various foreign and Russian pedagogical and methodological papers. The most studied components of the professional competence of a foreign language teacher are communicative, didactic and methodological competences. These competences can be considered as universal ones (Komiakova, 2013, pp. 186187). It has been stated that not all the competences of this complicated phenomenon have been studied thoroughly. One of its components is philological competence which has an important status in the structure of the professional competence of a foreign language teacher.

To understand the essence of the term "philological competence" of a foreign language teacher it is necessary to point out various definitions of the term "philology". In methodological dictionaries it is defined as a set of humanities, studying the culture of a nation, expressed in the language and in literature (Linguistic didactic encyclopedic dictionary, 2007, p. 367; New dictionary of methodological terms and notions (theory and practice of teaching foreign languages), 2009, pp. 337-338). Very close

(C) Siberian Federal University. All rights reserved

* Corresponding author E-mail address: irina-komyakova@yandex.ru 
to it is the definition given in the comprehensive dictionary of the Russian language where it is presented as a set of humanities, studying spiritual (mental) culture of a nation expressed in the language and in literature (linguistics, study of literature, study of folklore, textual criticism/study) (Comprehensive dictionary of the Russian language, 2007). According to O.A. Akhmanova, philology is a general name of subjects studying language, literature and culture of the nation through literature and other cultural and historical works (Dictionary of linguistic terms, 2010, pp. 492493). In Bloomsbury English Dictionary it is defined as study of language in texts, study of ancient texts, and study of literature (Bloomsbury English Dictionary, 2004, p. 1409). Thus, the key ideas represented in these definitions correlate philology with the field of humanities in which spiritual (mental) culture of a nation expressed in the language is perceived. We cannot but accept the point of view of G.O. Vinokur who said that philology has a great and inexhaustible cultural and educational meaning. Philology is an art of reading, and a philologist is a master of reading (Vinokur, 2000, p. 54).

According tomethodologicalinterpretations of philology, we can rely on the point of view of E.N. Solovova and E.A. Porechenkova. These scientists consider philology not only as an independent science, but as a field of study, comprising several sciences with one goal - to learn spiritual achievements of human society by learning a language in which these or those works are created and culture without knowing which it is impossible to understand these works totally (Solovova, Porechenkova, 2007, p. 5). The language must not be learnt in isolation without learning culture, thus any person who is learning a foreign language must have a developed philological competence (Porechenkova, 2009, p. 8).
Thus, it is evident that the professional training of such specialists as a linguist-translator, a teacher of a foreign language, a specialist in intercultural communication, as well as a teacher of a native language requires the development of philological competence.

\section{Conceptions of Philological Competence}

As for the term "philological competence" itself, the study of linguistic, linguistic didactic and methodological dictionaries has shown that this phenomenon has not been registered in them yet. According to it we can conclude that this term is rather new, has not been studied thoroughly and is needed to be investigated in detail especially in the situation when the professional training of a foreign language teacher (bachelor) is being reformed.

The problem of development of philological competence among future linguists, teachers of a foreign language, specialists in intercultural communication has been studied by such Russian scholars as L.V. Polubichenko, E.N. Solovova, E.A. Porechenkova, K.S. Makhmurian, V.V. Safonova, IU.V. Tkacheva, I.V. Treshina. Similarly, philological component of the professional competence of a philologist is represented in the works by T.M. Balikhina, M.I. Vitoshko, N.A. Belova.

It must be noted that the points of view of the scholarsaremostlysimilar. However, thereis some difference in the use of terminology. For instance, V.I. Blinov, E.N. Solovova, K.S. Makhmurian, L.V. Polubichenko, E.A. Porechenkova, IU.V. Tkacheva, I.V. Treshina, N.A. Goncharova consider philological competence in its narrow meaning, as a combination of knowledge, ability and skills which are formed within this or that subject/discipline. Another group of scholars define philological competence in its wider meaning as a set of competences which 
provide the readiness for professional activity. In our research we support the first position as the investigated competence is one of the components of the professional competence of Bachelors of Education (Major in Foreign Languages).

It has been studied that in the works of K.S. Makhmurian, L.V. Polubichenko, E.A. Porechenkova, E.N. Solovova philological competence has been analysed more thoroughly. Despite the fact that the viewpoints of these scholars are similar, the emphasis on the philological competence has been placed in different ways.

\section{Approaches to characteristics of philological competence}

To specify the essence of the philological competence with reference to Bachelors of Education (Major in Foreign Languages) it is necessary to reveal its core characteristics. As a result of analyzing theoretical research papers, we have distinguished several approaches to the characteristics of the philological competence.

According to the first approach the definition of philological competence is mostly related to the cognitive framework. A philologist must have knowledge in linguistics (such as the structure of a native and a foreign languages), in general humanities (knowledge of the history, literature and culture of native and foreign countries) (T.M. Balikhina, K.S. Makhmurian, M.IU. Mikhailova, L.V. Polubichenko, V.V. Safonova, E.N. Solovova, I.V. Treshina).

The second approach deals with the characteristics of philological competence that is oriented on the functioning framework. To them belong:

- the ability to give a complex philological analysis of texts in different genres (K.S. Makhmurian);
- the ability to interpret the context of texts (K.S. Makhmurian, L. V. Polubichenko, E.N. Solovova);

- the ability to explain linguistic and literary peculiarities of texts (K.S. Makhmurian);

- the ability to interpret the phenomena of foreign and native languages (IU.V. Tkacheva);

- the ability to explain difficult and incomprehensible parts of texts to various groups of people (L.V. Polubichenko, E.N. Solovova);

- to know the reading techniques (K.S. Makhmurian);

- to know the basis of rhetoric (K.S. Makhmurian, V.V. Safonova, E.N. Solovova);

- to have the skills of self-study work (E.A. Porechenkova);

- to be able to solve foreign communicative, pedagogical and scientific research tasks (N.A. Goncharova).

The third approach is related to the personal traits of a specialist. According to the authors a teacher of a foreign language must have

- developed spiritual/mental qualities such as codes of conduct, moral ideals (E.A. Porechenkova);

- philological keenness of observation, philological inquisitiveness, philological thinking, philological responsibility (K.S. Makhmurian).

The fourth approach to defining the structure and the content of philological competence is connected to its consideration through the prism of other competences (competence framework). There are some studies in which the authors state only those competences that are included in it (V.I. Blinov, K.S. Makhmurian, E.N. Solovova, 2000).

Finally, the fifth approach is the combination of all the above mentioned 
frameworks: cognitive, functioning, personal and competence. This approach is mentioned in the works of E.A. Porechenkova (2009) and K.S. Makhmurian $(2005,2009)$. In that way, this approach is the most complete and correspond to modern requirements of training specialists.

\section{Conclusion}

Within this article we have distinguished the approaches to philological competence of Bachelors of Education (Major in Foreign Languages). The training of a foreign language teacher must be realized on the basis of a competence-based approach and include the development of philological competence which is a multicomponent phenomenon. Only applying interdisciplinary approach it is possible to gain the aim of higher education train a professional foreign language teacher.

\section{References}

Bloomsbury English Dictionary. K. Rooney. London: Bloomsbury, 2004. 2166 p.

Komiakova, I.M. K probleme opredeleniia komponentnogo sostava professional'noi kompetentsii uchitelia inostrannogo iazyka-bakalavra [To the problem of defining the component system of the professional competence of a Bachelor of Education (Major in Foreign Languages)]. Teoriia i praktika obucheniia inostrannym iazykam: traditsii i innovatsii: Sbornik statei mezhdunarodnoi nauchnoprakticheskoi konferentsii pamiati akademika RAO I.L.Bim (Theory and practice in teaching foreign languages: traditions and innovations: proceedings of the international scientific practical conference in memory of academician RAE I.L. Bim). Moscow, 2013, pp. 183-190.

Lingvodidakticheskii entsiklopedicheskii slovar' [Linguistic didactic encyclopedic dictionary]. A.N. Shchukin. Moscow, 2007. 746 p.

Makhmurian, K.S. (2008). Soderzhanie poniatii "filologiia" $i$ "filologicheskaia kompetentsiia" na sovremennom etape [The meaning of terms "philology" and "philological competence" at present days]. Bulletin of Moscow State University, Vol.19 Linguistics and intercultural communication, (3), 202-207.

Novyi slovar' metodicheskikh terminov i poniatii (teoriia i praktika obucheniia iazykam) [New dictionary of methodological terms and notions (theory and practice of teaching foreign languages]. E.G. Azimov, A.N. Shchukin. Moscow, 2009. 448 p.

Porechenkova, E.A. Razvitie filologicheskoi kompetentsii v sisteme shkola-vuz i sposoby ee kontrolia [Development of philological competence in the system comprehensive school - high school and the ways of control. Dissertation Abstract of Candidate of Education]. Moscow, 2009. 20 p.

Slovar' lingvisticheskikh terminov [Dictionary of linguistic terms]. O.S. Akhmanova. Moscow, 2010. $576 \mathrm{p}$.

Solovova, E.N., Porechenkova, E.A. (2007). Opredelenie sostava filologicheskikh nauk [Defining the structure of philological sciences]. Foreign Languages at School, (8), 2-8.

Tolkovyi slovar' russkogo iazyka s vkliucheniem svedenii o proiskhozhdenii slov [Comprehensive dictionary of the Russian language]. N.IU. Shvedova. Moscow, 2007. 1175 p.

Vinokur G.O. Sobranie trudov: vvedenie v izuchenie filologicheskikh nauk [Collection of works: introduction to studying philological sciences]. Moscow, 2000. $192 \mathrm{p}$. 


\section{Подходы к определению филологической компетенции \\ как неотьемлемой части \\ профессиональной компетентности \\ учителя иностранного языка}

И.М. Комякова

Государственный социально-гуманитарный университет Россия, 140410, Московская область, Коломна, ул. Зеленая, 30

Статья посвящена рассмотрению вопросов, касающчихя филологической компетенции и необходимости ее формирования в процессе подготовки бакалавров педагогического образования (профиль «Иностранный язык») в высшей школе. Прежде всего, представлень различные точки зрения на понятия «филология» и «филологическая компетениия». Также в статье выделяются некоторые подходы к определению характеристик филологической компетениии, необходимых будущему учителю иностранных языков. В результате предлагается вывод относительно сущцноти филологической компетенции учителя иностранного языка и формирование ее на основе междисииплинарного подхода.

Ключевые слова: филологическая компетенция, бакалавр педагогического образования (профиль «Иностранный язык»), профессиональная компетенция учителя иностранного языка, междисииплинарный подход.

Научная специальность: 13.00.02 - Теория и методика обучения и воспитания (иностранные языки). 